\title{
Introduction: Indigenous Perspectives on Genealogical Research
}

\author{
Nēpia Mahuika ${ }^{1, *}$ and Tahu Kukutai ${ }^{2}$ (D) \\ 1 History Programme, The University of Waikato, Hamilton 3240, New Zealand \\ 2 National Institute of Demographic and Economic Analysis, The University of Waikato, \\ Hamilton 3240, New Zealand; tahu.kukutai@waikato.ac.nz \\ * Correspondence: nepia.mahuika@waikato.ac.nz
}

Citation: Mahuika, Nēpia, and Tahu Kukutai. 2021. Introduction: Indigenous Perspectives on Genealogical Research. Genealogy 5: 63. https://doi.org/10.3390/ genealogy5030063

Received: 23 February 2021

Accepted: 26 June 2021

Published: 6 July 2021

Publisher's Note: MDPI stays neutral with regard to jurisdictional claims in published maps and institutional affiliations.

Copyright: (c) 2021 by the authors. Licensee MDPI, Basel, Switzerland. This article is an open access article distributed under the terms and conditions of the Creative Commons Attribution (CC BY) license (https:// creativecommons.org/licenses/by/ $4.0 /)$.
Indigenous genealogies encompass complex layers of connection within and between human, environment and spirit, realms. The collective genealogies that underpin Indigenous identity thus reach far beyond ancestral lineage to include our creation stories, relationships with land, water, plants, animals and cycles of nature, protocols for ethical behaviour and imaginings of future descendants alongside memories of past ancestors. At the same time, the evolving context of Indigenous genealogies means that they are inherently dynamic and fluid; genealogy does not exist as a self-reinforcing body of knowledge in sequential time waiting to be "passed on" in a linear fashion or "discovered" in archives and registries. The dispossession and trauma wrought by historical colonisation and enduring colonialism has also impacted our genealogical legacies, creating holes and tears in the weaves that once bound us tight.

The concept of "Indigenous lifeworlds" (Walter and Suina 2019) captures well the dual intersubjectivities of contemporary Indigenous realities: that of peoplehood rooted in the deep history of our lands, culture, traditions and ways of knowing; and that of being marginalised peoples whose everyday life is impacted by our historical and ongoing relationship with the colonial nation state. Within these lifeworlds, Indigenous peoples continue to find ways to enhance and enable genealogical knowledge to tell our stories, to reflect our traditional and contemporary values, and operate as significant cultural frameworks relevant to our collective identities.

As Indigenous peoples, our identities are inherently political. The use of genealogies to buttress (and often contest) negotiations with Governments underscore the political nature of genealogy and genealogical remembering. Likewise, the interplay with new technologies such as DNA testing also remind us that what appear to be "objective" or scientific truths are the products of power dynamics situated in particular social, historical and political contexts. New DNA technologies that purport to determine ancestral belonging may be new in design, but not in consequence. As Kim Tallbear (Tallbear 2013a) deftly argues in Native American DNA: Tribal belonging and the false promise of genetic science, DNA testing is a continuation of long-standing practices of selectively using scientific knowledge to classify Native bodies in ways that serve powerful interests.

It is no surprise, then, that in an era of pervasive datafication (van Dijck 2014) and data colonialism (Couldry and Mejias 2019) genealogical research is big business. Family history and genealogy is one of the most popular online activities. Ancestry.com, the largest genealogy company in the world, has amassed 13+ billion ancestral profiles. Its 2012 spinoff AncestryDNA has more than 18 million entries in its consumer DNA database and is now one of the world's biggest providers of Direct-to-Consumer Genetic Testing (DTCGT) (ancestry.com 2021; Moore et al. 2021). The conflation between the genealogical and genetic is profoundly reshaping peoples relationships to their pasts (de Groot 2020), with far-reaching consequences for Native peoples (Garrison et al. 2019; Reardon and TallBear 2012; Tallbear 2013b). 
The contest for Indigenous identities and the rights to claim Native-ness are part of the historiography of genealogical research and practice, but have been supercharged with the turn to genetics and DTCGT. White settler "self-Indigenisation" is just one intersection where genealogy forums and online sites are used by non-Indigenous peoples to assert claims to Indigeneity. As Darryl Leroux observes in Distorted descent White claims to Indigenous identity (Leroux 2019), such claims-while flawed on many fronts-also wilfully ignore long-standing Indigenous conventions about citizenship and kinship and what Métis scholar Chris Andersen (2014) calls "relational peoplehood".

As Indigenous peoples, our ways of defining genealogical meaning, knowledge and practice have tended to feature on the margins of genealogical scholarship, if at all. By contrast, this special issue of Genealogy intentionally centres Indigenous genealogical knowing and practice. Written by Indigenous scholars across diverse disciplines, the contributions in this issue reaffirm that identity is a crucial and complex part of the way genealogies are used and understood in different Indigenous communities. Indeed, the very meaning of genealogy has its own nuanced assertions in Indigenous contexts.

Our call to Indigenous scholars in this special issue is deliberate. The production of knowledge about Indigenous peoples has a long and fraught history. Through scientific practices of observation and documentation, Indigenous peoples and knowledge systems came to be "discovered" and made legible to others, initially through the writings of early travellers, explorers and scientists and later through Government and academic research (Smith 1999). These processes and practices positioned non-Indigenous peoples as the credible knowers of all things Indigenous-indeed, these "experts" purported to know us better than we knew ourselves. Set against this backdrop, this special issue provides a purposeful space for the distillation of unapologetically Indigenous worldviews and diverse methodological approaches to genealogical research. In so doing it builds on previous Indigenous-focused special issues of Genealogy including: Decolonizing ways of knowing: Heritage, living communities and Indigenous understandings of place; and Community-engaged Indigenous research across the globe. Along with prior special issues, this assemblage lays the path for future Indigenous genealogical scholarship in this journal and elsewhere (see forthcoming special issues: Landin' the Spirit: Indigenous knowledge on healing and wellbeing; Storying Indigenous (Life) Worlds; Indigenous identity and community; and, Indigenous ethnography: How does one conduct Indigenous research and Indigenous anthropology?).

A recurring theme in this special issue is that genealogies are kept and practiced as performed, living narratives. This marriage of biography and narrative is crucial to Indigenous uses and conceptions of genealogical knowledge that is "as much about the present and the future as it is about the past" (Chang 2016, p. 76). Genealogies are not just a keeping and reciting of our lines of names and descent, but are part of a lineage of thinking and custodianship. In our "sea of archives", Indigenous peoples respond to ourselves and our own intellectual genealogies, repopulating and repeating "the prior acts of reaching by [our] ancestors" (Te Punga Somerville 2017, p. 124). Some Indigenous scholars write about "a genealogy of thinkers" within which we, as students, get to "choose the ancestors" we see as our "intellectual kin" (Teaiwa 2014, pp. 50-51, 53). Genealogy is more than just "blood and bone" and can extend, as Aroha Harris explains, "to the whakapapa (Māori genealogy, added) of experience, of deeds and desires" (Harris 2009, p. 84).

Indigenous peoples have generations of evolving and intricate genealogical knowledge and lived experience to share with the world. The authors in this special issue cover a broad, yet interconnected, array of ideas and insights about genealogy. They write about genealogy using the language and words common in their communities. For most, the retention and evolution of their inherited collective Indigenous identities and ways of knowing are key themes when interrogating the place and meaning of genealogy in their research and lives. For these authors, genealogy is more lived than learnt. It is crucial to healing, decolonization and empowerment. 
In "Miskâsowin: Indigenous science, technology and society," Ininiw/Cree scholar Jessica Kolopenuk (Kolopenuk 2020) explores the theme of genealogy "through a language of relationality/ies" (p. 2). In explaining her own set of methodological relations, she introduces readers to miskâsowin-a Cree word that means "to remember one's core" (p. 6). As Kolopenuk writes, "We know the stars as ancestors and ourselves" (p. 6). This is more than "a metaphorical story" - it is an epistemological frame wherein we express a "coming to know" that reorients and empowers (p. 7). Miskâsowin is "infinite action" (p. 6) and involves severing "the attachments Indigenous peoples have to the stories that frame us as not belonging in our homelands and as always somehow constitutionally lacking" (p. 7).

For many Indigenous communities, genealogy is part of the storying of our connections to, and origins in, the land, seascapes, skies and spiritual realms that are our homes and "core". Our genealogies are very often powerful statements of belonging, ownership and, what Anishinabe scholar Gerald Vizenor calls "survivance" (Vizenor 2009). In her article, Sami scholar Isabelle Brännlund, considers a "genealogy of place" (Brännlund 2019, p. 9) and how genealogy, kinship and place intersect with "questions of identity and land rights" (p. 1). She discusses the central role that reindeer husbandry has played in negotiations of identity, noting the "internal exclusions" based on criteria for belonging and the use of taxation records and title transfers that followed a pattern of inheritance over generations (p. 8). Brännlund shows how place names (and names of other Sami taxation lands) were not only used in the context of tax payments, but also as an "intercultural identifier" (p. 8). This genealogical origin and relation to land or place (a genealogy of place) includes "tales about forebears, hunting traditions and sacred sites in the area, revealing an understanding of place attachment as a shared cultural group experience" (p. 10). Identity, as it was for Kolopenuk, is a critical theme. For both, local genealogical markers, frameworks and criteria are not static but constantly evolving and therefore "a matter of "becoming" as well as of "being" (p. 2). In these ways, genealogy in Indigenous communities is a living contemporary practice of knowing and being, tied to changing political, technological and cultural phenomena. But, as the authors reveal, are best known through persisting and transforming Indigenous epistemologies.

Other authors in this special issue accentuate the genealogical ties that Indigenous peoples maintain to the environment and how important this is to political assertions of power and belonging. Exploring the way whakapapa is acknowledged as a template for environmental order and acknowledging place-specific relationships, Rongomaiwahine scholar Margaret Forster examines how whakapapa "can map origin and relationships" and provides "narratives that can be used to guide interactions with specific natural resources and ecosystems such as the cultivation of kumara (sweet potato)" (Forster 2019, p. 2). Forster's essay tells us that Māori genealogies are most commonly deployed as narratives, are used to explain social phenomena and provide a "system of thought based on an interrelatedness that establishes connections with ancestors and the environment and creates culturally appropriate ways of acting" (p. 3). As she writes, "[W]hen whakapapa (genealogy) is absent within day-to-day activities ... connections to ancestors and the environment weaken" (p. 4). We can, then, see our health tracked in the presence and absence of whakapapa in our lives. Forster explores the notion of "whakapapa sequences" and narratives that provide a framework for understanding Te Ao Maori (the Māori world) (p. 5) and demonstrates how new sequences can be created to challenge narratives of domination and suppression. Whakapapa sequences, she argues, bring together the physical, intellectual and cultural to explain how Maori conceptualise the world and develop practices for regulating interactions with the environment (tikanga tiaki).

All of the essays note how Indigenous genealogical knowing and practice are key to local assertions of custodianship that also serve as powerful expressions of native political, cultural and spiritual identities. Knowing our genealogy, then is about knowing ourselves and deliberately showcasing that genealogy to new generations. Indigenous genealogies speak to our epistemological frames of reference, relationships with ancestors 
and the environment. Ongoing political ambitions are part of native methodologies and pedagogies. The pedagogical value of genealogy is explored in Melinda Webber (Ngāti Whakaue, Ngāti Kahu) and Kaupua O'Connor's (Ngāti Kuri) essay, "A Fire in the Belly of Hineāmaru" (. Webber and O'Connor 2019). Using specific tribal genealogical narratives, including those of the renowned female leader Hineamaru and the nineteenth century leader Kāwiti, Webber and O'Connor argue that learning about inspirational figures like these can motivate and foster a greater interest in Māori students and can challenge the "persistent rhetoric relating to Maori underachievement and deficit theorising" (p. 2). They write that teaching students about whakapapa and ways of knowing can be considered "a decolonising project" (p. 2). Webber and O'Connor's "Whakapapa as Pedagogy", then, strengthens the ties between individuals and their multiple whānau (family), hapu (subtribes) and iwi (tribes), who share a common genealogy (p. 3). In privileging Māori genealogical stories and incorporating strengths-based narratives of survivance, Webber and $\mathrm{O}^{\prime}$ Connor argue that Māori stories of entrepreneurship, ingenuity, innovation, astrological knowledge, construction of defensive earthworks and trench warfare, remind Māori students that they descend the from the "greatness" (p. 2) of "illustrious" and "inspiring" ancestors (p. 12). Genealogy for Indigenous peoples, then, can be thought of as methodological, pedagogical and based in local epistemologies. The authors continually show that genealogy for Indigenous peoples is highly politically and often a tool to revitalize, empower, heal and decolonize.

Genealogical research and work for Indigenous peoples is often about keeping us together in the face of colonial invasions, identity, land and language loss, erasure and disconnection. This is the focus in CHamoru scholar Bernard Punzalan's essay, where he explores the many challenges CHamoru peoples' face in retaining their connections following generations of substantive diaspora shifts to the United States (Punzalan 2019). Chamorro identity, he argues, is inextricably intertwined in a complex colonial history that include the replacement of Indigenous first names with Christian names (p. 1). The "Chamorro Roots Genealogy Project", Punzalan writes, "initially started out as a family roots project, and eventually evolved into a community-wide project for the CHamoru people" (p. 2) and has been "trying to fill those gaps" (p. 2) and disconnections brought about by colonialism and diasporic mobilities. Punzalan sees the modern Indigenous genealogist as one who is increasingly finding ways to keep and protect our genealogical knowledge. These were once revered members of native communities entrusted with tribal and collective knowledge that storied our lives together. As Punzalan's essay reveals, these roles are increasingly adapting, as Indigenous genealogists experiment with new technologies, critically engage with census databases and find ways to recentre our genealogical words, knowledge and practices in the process.

While in the majority of essays in this special issue focus on the ways in which Indigenous scholars and communities are using genealogical work and approaches to teach, challenge, reconnect and privilege, Ngāti Porou scholar Nēpia Mahuika offers a brief exploration of the way whakapapa (Māori genealogy) has been used, challenged and adapted, by researchers and Māori in Aotearoa New Zealand (Mahuika 2019). Mahuika, for instance, notes the way whakapapa was used to suggest an arrival date for early Māori voyagers and that this method of dating was later critiqued and rejected by researchers. Whakapapa, he writes, has been defined, used and researched in various ways in tribal histories, songs, the written proceedings of land courts designed to alienate Maori land, personal memoirs, Māori newspapers, carving, biographies and private family books. There are different types of whakapapa, Mahuika argues that may be thought of as "states", "divisions" (p. 4) or what Forster refers to as "sequences".

Mahuika points out how whakapapa is, and has, its own language and rules of engagement (tikanga). As a topic of research, he writes that whakapapa "changed with the arrival of Europeans, whose incredulity of oral histories" undermined traditional experts and often displaced Māori genealogical accounts of our ancestors as "unreliable superstitions and myth" (p. 4). Nevertheless, Māori used, mixed and experimented with 
Western genealogical methods, sometimes embracing and rejecting new technologies and ideas in an effort to keep control of our own knowledge. Māori genealogy, he writes, were traditionally taught in wānanga (specific schools of learning) and included specific practices and terminologies. Like the other authors, Mahuika emphasizes the fact that Indigenous understandings and uses of genealogy have their own tribal or community specific politics "that seek out connections and inclusivity and are necessarily exclusive when it comes to exercising and asserting ownership and authority" (p. 10).

This special issue provides an insight into different Indigenous methodologies of genealogy, how it matters to their communities and how it is a living practice that evolves and changes as Indigenous peoples find new and innovative ways to re-present and share our genealogical knowledge to new generations. Taking this ownership of our genealogies is a political act of power and, in particular, of ownership and autonomy. Where these acts involve the repatriation, digitisation and integration of genealogical data, emerging concepts of Indigenous data sovereignty (Walter et al. 2020) and Indigenous data governance (Carroll et al. 2020) are becoming increasingly relevant. For scholars in the field, and for those who are not Indigenous, these essays provide an insight into the ways Indigenous genealogy research matters for Native peoples, the environment and challenges to colonial power and the production and perpetuation of assimilative nation-states. As the authors show us, genealogy for Indigenous peoples, is a deeply informative framework and a constantly transformative body of knowledge that can be healing and decolonial.

Author Contributions: Conceptualization, methodology, and writing, N.M., T.K.; funding acquisition, T.K. All authors have read and agreed to the published version of the manuscript.

Funding: This research was funded by the Marsden Fund (UOW1605).

Institutional Review Board Statement: Not applicable.

Informed Consent Statement: Not applicable.

Conflicts of Interest: The authors declare no conflict of interest.

\section{References}

ancestry.com. 2021. Available online: https:/ / www.ancestry.com/corporate/about-ancestry/company-facts (accessed on 1 July 2021). Andersen, Chris. 2014. Métis: Race, Recognition, and the Struggle for Indigenous Peoplehood. Vancouver: UBC Press.

Brännlund, Isabelle. 2019. Familiar places: A history of place attachment in a South Sami community. Genealogy 3: 54. [CrossRef]

Carroll, Stephanie Russo, Ibrahim Garba, Oscar L. Figueroa-Rodríguez, Jarita Holbrook, Raymond Lovett, Simeon Materechera, Mark Parsons, Kay Raseroka, Desi Rodriguez-Lonebear, Robin Rowe, and et al. 2020. The CARE Principles for Indigenous Data Governance. Data Science Journal 19: 1. [CrossRef]

Chang, David. 2016. Indigenous biography, genealogy, and webs of relation. Biography 39: 274-76. [CrossRef]

Couldry, Nick, and Ulises Mejias. 2019. Data colonialism: rethinking big data's relation to the contemporary subject. Television and New Media 20: 336-49. [CrossRef]

de Groot, Jerome. 2020. Ancestry.com and the evolving nature of historical information companies. The Public Historian 42: 8-28. [CrossRef]

Forster, Margaret. 2019. He tātai whenua: Environmental genealogies. Genealogy 3: 42. [CrossRef]

Garrison, Nanibaa'A., Māui Hudson, Leah L. Ballantyne, Ibrahim Garba, Andrew Martinez, Maile Taualii, Laura Arbour, Nadine R. Caron, and Stephanie Carroll Rainie. 2019. Genomic research through an Indigenous lens: Understanding the expectations. Annual Review of Genomics and Human Genetics 20: 495-517. [CrossRef] [PubMed]

Harris, Aroha. 2009. Theorize this: We are what we write. Te Pouhere Kōrero 3: 83-9.

Kolopenuk, Jessica. 2020. Miskâsowin: Indigenous science, technology, and society. Genealogy 4: 21. [CrossRef]

Leroux, Darryl. 2019. Distorted Descent White Claims to Indigenous Identity. Winnipeg: University of Manitoba Press.

Mahuika, Nēpia. 2019. A brief history of whakapapa: Māori approaches to genealogy. Genealogy 3: 32. [CrossRef]

Moore, Susan, Doreen Rosenthal, and Rebecca Robinson. 2021. The Psychology of Family History: Exploring Our Genealogy. Abingdon: Routledge.

Punzalan, Bernard. 2019. Chamorro Roots genealogy project: Technological milestones. Genealogy 3: 38. [CrossRef]

Reardon, Jenny, and Kim TallBear. 2012. Your DNA is our history: Genomics, anthropology, and the construction of whiteness as property. Current Anthropology 53: S233-45. [CrossRef]

Smith, Linda Tuhiwai. 1999. Decolonizing Methodologies: Research and Indigenous Peoples. New York: Zed books. 
Tallbear, Kim. 2013a. Native American DNA: Tribal Belonging and the False Promise of Genetic Science. Minneapolis: University of Minnesota Press.

Tallbear, Kim. 2013b. Genomic articulations of indigeneity. Social Studies of Science 43: 509-33. [CrossRef]

Te Punga Somerville, Alice. 2017. "I do still have a letter": Our sea of archives. In Sources and Methods in Indigenous Studies. Edited by Andersen Chris and Jean O'Brien. Abingdon: Routledge, pp. 212-27.

Teaiwa, Teresia. 2014. The ancestors we get to choose: White influences I won't deny. In Theorizing Native Studies. Edited by Simpson Audra and Andrea Smith. Durham: Duke University Press, pp. 43-55.

van Dijck, Jose. 2014. Datafication, dataism and dataveillance: Big Data between scientific paradigm and ideology. Surveillance and Society 12: 197-208. [CrossRef]

Vizenor, Gerald R., ed. 2009. Survivance: Natural Reason and Cultural Survivance. Lincoln: University of Nebraska Press.

Walter, Michele, Tahu Kukutai, Stephanie Russo Carroll, and Desi Lonebear, eds. 2020. Indigenous Data Sovereignty and Policy. London: Routledge.

Walter, Maggie, and Michele Suina. 2019. Indigenous data, indigenous methodologies and indigenous data sovereignty. International Journal of Social Research Methodology 22: 233-43. [CrossRef]

Webber, Melinda, and Kapua O'Connor. 2019. A fire in the belly of Hineāmaru: Using whakapapa as a pedagogical tool in education. Genealogy 3: 41. [CrossRef] 